\title{
Using daptomycin for the treatment of surgical site infections in a single neurosurgical unit - preliminary experience
}

\author{
Nilolaos Syrmos ${ }^{*}$, Charalampos Iliadis, Konstantinos Grigoriou, Vasileios Valadakis, Dimitrios Arvanitakis \\ From $1^{\text {st }}$ International Congress on Neurobiology and Clinical Psychopharmacology and European \\ Psychiatric Association Conference on Treatment Guidance \\ Thessaloniki, Greece. 19-22 November 2009
}

\section{Background}

The increasing frequency of methicillin-resistant Staphylococcus aureus as a cause of surgical site infections, and decreased susceptibility to vancomycin, highlight the need for alternative therapies. Daptomycin is a novel lipopeptide antibiotic used in the treatment of certain infections caused by Gram-positive organisms. It is a naturally-occurring compound found in the soil saprotroph Streptomyces roseosporus. Its distinct mechanism of action means that it may be useful in treating infections caused by multi-resistant bacteria Daptomycin is approved for the treatment of skin and skin-structure infections $(4 \mathrm{mg} / \mathrm{kg})$, and Staphylococcus aureus bacteremia, including right-sided endocarditis $(6 \mathrm{mg} / \mathrm{kg})$.

\section{Aim}

To evaluate the safety and efficacy of daptomycin when administered for a variety of gram-positive infections in a single neurosurgical unit.

\section{Materials and methods}

During the last three years we use damtomycin (20062007-2008) in 64 cases. For the purpose of this study, the safety and efficacy of daptomycin were evaluated in patients who received doses of $4 \mathrm{mg} / \mathrm{kg}$ or higher. Prior antibiotic therapy was given to $21,8 \%$ of patients (14).

\section{Results}

The median final daptomycin dose was $5 \mathrm{mg} / \mathrm{kg}$. The median duration of daptomycin therapy was 15 days. Daptomycin was well tolerated in patients with grampositive infections. The most common infections were skin and skin-structure. The most common pathogens were $\mathrm{S}$. aureus.

1. A large number of novel antibacterial agents have been or are being developed for the treatment of complicated skin and soft tissue infections -cSSTIs -Daptomycin is one of them and it is available for clinical use. 2.Daptomycin was well tolerated in patients with grampositive infections. 3. Further prospective and comparative studies of daptomycin are warranted.

\section{Conclusions}

We have always to rememder that the most mportant parameters that appear to determine the clinical effectiveness of an antibiotic for cSSTIs include the severity of the illness, patient co-morbidities, whether the patient receives appropriate antimicrobial therapy at the onset of illness and if this should be a combination or singleagent approach to cover a broad range of likely causative organisms.

\section{Acknowledgements}

Special thanks to Mr Panagiotis Stratigakis.

Published: 22 April 2010

\section{References}

1. Chamberlain RS, Culshaw DL, Donovan BJ, Lamp KC: Daptomycin for the treatment of surgical site infections. Surgery 2009, 146(2):316-24.

2. Fenton C, Keating GM, Curran MP: Daptomycin. Drugs 2004, 64(4):445-55, discussion 457-8.

3. Moise PA, Hershberger E, Amodio-Groton MI, Lamp KC: Safety and clinical outcomes when utilizing daptomycin therapy in a neurosurgical department. Ann Pharmacother 2009, 43(7):1211-9.

4. Nathwani D: New antibiotics for the management of complicated skin and soft tissue infections: are they any better? Int J Antimicrob Agents 2009, 34(Suppl 1):S24-9.

Neurosurgical Department-Venizeleio General Hospital, Herakleio, Greece 
5. Quetglas EG, San Julian M, Garcia Tutor E, Vazquez B, Lucena F,

Landecho M, Azanza JR: A long-term retrospective review of 5 cases

using daptomycin for prosthetic device infections after surgery. Int J Artif Organs 2009, 32(5):299-307.

6. Sorlozano A, Gutiérrez J, Roman J, Liebana J, Piedrola G: Activity of daptomycin against multiresistant clinical isolates of Staphylococcus aureus and Streptococcus agalactiae. Microb Drug Resist 2009, 15(2):125-7.

doi:10.1186/1744-859X-9-S1-S101

Cite this article as: Syrmos et al:: Using daptomycin for the treatment of surgical site infections in a single neurosurgical unit - preliminary experience. Annals of General Psychiatry 2010 9(Suppl 1):S101.

Submit your next manuscript to BioMed Central and take full advantage of:

- Convenient online submission

- Thorough peer review

- No space constraints or color figure charges

- Immediate publication on acceptance

- Inclusion in PubMed, CAS, Scopus and Google Scholar

- Research which is freely available for redistribution

Submit your manuscript at www.biomedcentral.com/submit
C Biomed Central 